\title{
An assessment of spatial and temporal variation in the diet of Cape clawless otters (Aonyx capensis) in marine environments
}

\author{
Rowan K. Jordaan ${ }^{1 *}$, Trevor McIntyre, Michael J. Somers ${ }^{2}$ \& \\ Marthán N. Bester ${ }^{1}$ \\ ${ }^{1}$ Mammal Research Institute, Department of Zoology and Entomology, University of Pretoria, \\ Private Bag X20, Hatfield, 0028 South Africa \\ ${ }^{2}$ Centre for Wildlife Management, Centre for Invasion Biology, University of Pretoria, \\ Private Bag X20, Hatfield, 0028 South Africa \\ Received 6 May 2015. To authors for revision 15 June 2015. Accepted 11 September 2015
}

\begin{abstract}
We studied the diet of Cape clawless otters (Aonyx capensis) at three sites along the eastern and southern coast of South Africa to assess possible spatial variation along a community species richness and biomass gradient associated with rocky shores. A total of 309 spraints representing two seasons (summer 2013/2014 and winter 2014) were collected and subsequently analysed. The percentage occurrence and percentage dry mass of numerous prey categories were compared between sites and seasons. Variation in the importance of prey items was found between sites, whilst no variation was found between seasons within the same site. Crab was the most important prey item in the southernmost study area (Tsitsikamma National Park) and at the northernmost study site (KwaZulu-Natal Coast), whilst lobster was the most important prey item in the central area (Mkambati Nature Reserve). Fish was the second most important prey item at all three sites. Our results suggest that otters are opportunistic feeders that are likely able to adapt to potential prey species and abundance changes associated with current and future anthropogenically driven changes. Furthermore, long-term, site-specific stability in diet suggests that monitoring the diet of otters could provide some useful information on the status of shoreline communities.
\end{abstract}

Key words: African clawless otters, African carnivores, spraints, prey, opportunistic feeding, monitoring.

\section{INTRODUCTION}

The coastline of southern Africa consists of three biogeographic provinces based on substantial differences in shoreline species composition, namely the cold-temperate west coast, warmtemperate south coast and the subtropical east coast provinces (Branch \& Branch, 1981; Field \& Griffiths, 1991). Abiotic factors, in particular wave action, are important in the structuring of rocky intertidal communities (Field \& Griffiths, 1991). Community species richness increases from the west coast to the south and east coasts and is accompanied with a decrease in community biomass from the west coast to the south and east coasts (Bustamante \& Branch, 1996).

The Cape clawless otter (Aonyx capensis) is the most widely distributed of the three endemic otter

\footnotetext{
*To whom corrrespondence should be addresssed.
}

E-mail: rowan.jordaan@zoology.up.ac.za species in Africa (Nel \& Somers, 2007). Its distribution range covers most of sub-Saharan Africa, only being absent in the Congo basin where it is replaced by the Congo clawless otter ( $A$. congicus) (Rowe-Rowe \& Somers, 1998; Nel \& Somers, 2007). Cape clawless otters occur in a large range of habitats including both coastal and inland habitats, with occurrences along the coast being closely associated with freshwater availability (van Niekerk, Somers \& Nel, 1998). They are semiaquatic predators with a prey base that mainly consists of aquatic species such as fish, frogs and crabs, and occasionally insects and other taxa (Rowe-Rowe \& Somers, 1998; Somers \& Nel, 2003). Within freshwater habitats, $A$. capensis is generally regarded as a crab specialist due to its broadened bunodont molars, and manual dexterity (Rowe-Rowe, 1977a,b).

The diet of $A$. capensis apparently differs between 
nearby marine locations (Emmerson \& Philip, 2004), and varies between seasons at marine sites and inland river systems (Rowe-Rowe, 1997a; Somers, 2000). Seasonal variation is attributed to the reduced efficiency in the locomotion shown by fish during winter when the water temperature is much cooler, therefore making fish more vulnerable to predation (Rowe-Rowe, 1975).

Our study investigated the spatial and temporal plasticity in the diet of Cape clawless otters at three coastal locations along the rocky shore species-richness and biomass gradient described by Bustamante \& Branch (1996). By comparing our results with earlier published accounts, we further aimed to assess long-term trends in the diet of Cape clawless otters recorded at two of the study sites.

\section{METHODS}

\section{Study sites}

\section{KZN Coast}

Our study area along the KwaZulu-Natal Coast (hereafter 'KZN Coast' ) comprised two sites along the Dolphin Coast in northern KwaZulu-Natal and Hibiscus Coast area in southern KwaZulu-Natal (Fig. 1). The area along the coast is typically made up of subtropical thickets and deep ravines with some steep slopes hosting afromontane forest. The coast has a subtropical climate with a mean annual rainfall of $1009 \mathrm{~mm}$. The mean surf zone temperature is $21.6^{\circ} \mathrm{C}$, but ranges from 12.8 $28.3^{\circ} \mathrm{C}$ (Harris et al., 1962). The area of the South Coast that was searched for spraints (otter faeces) included sites from Hibberdene in the north to the Zolwane River in the south (south of Port Edward) (Fig. 1).

\section{Mkambati}

Mkambati Nature Reserve (MK) is situated on the Transkei Wild Coast in the northern part of the Eastern Cape Province and has an abundance of freshwater in the form of coastal streams and estuaries (Whitfield, 1995). The reserve is bounded by the Mtentu River in the north and the Msikaba River in the south and is located in a rural area which is relatively free of pollution and disturbance

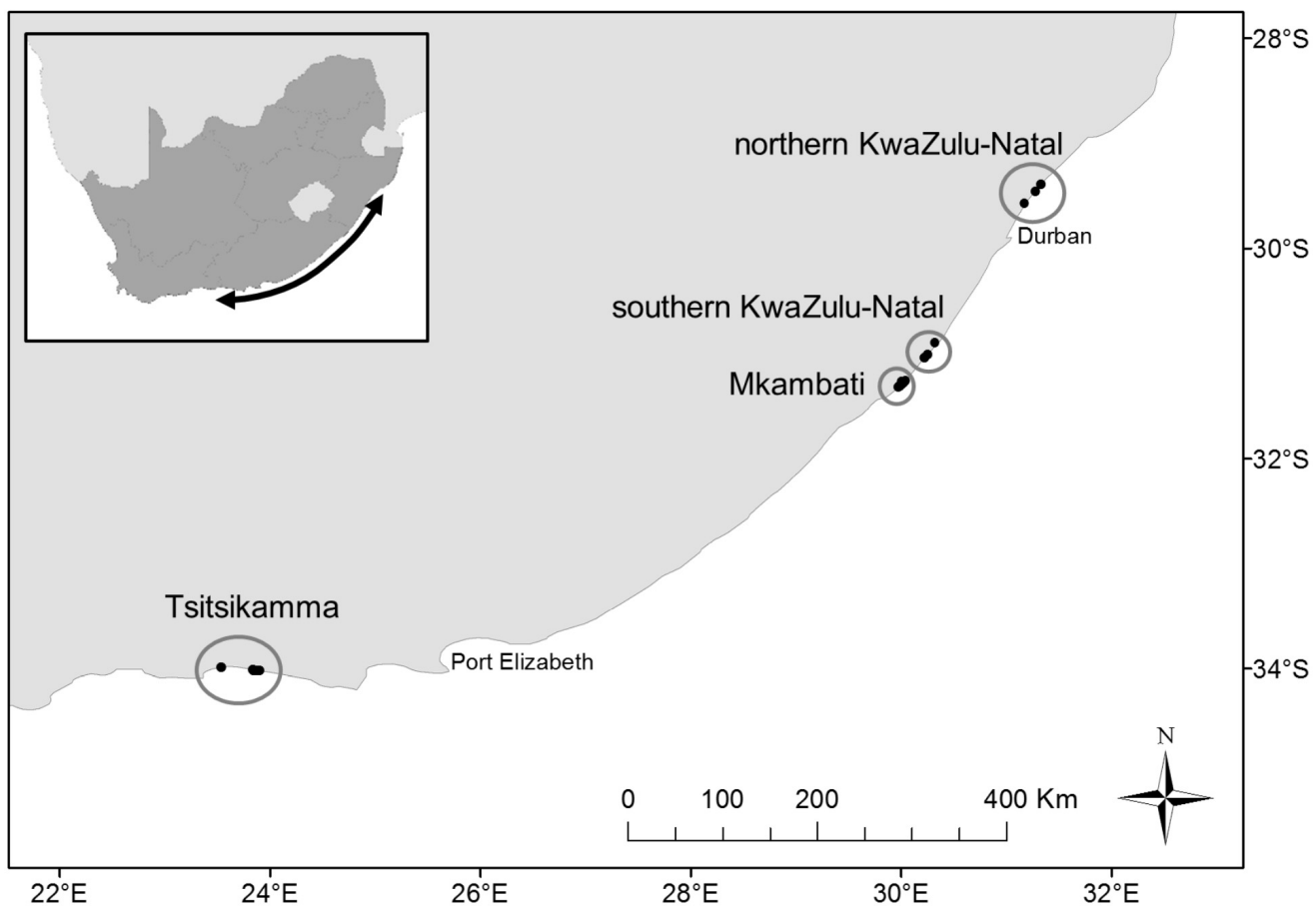

Fig. 1. Study areas located on the eastern and southern coastline of southern Africa. The inset indicates the location of the study areas (black arrow) in relation to the rest of South Africa (dark shading) and southern Africa. Although geographically close to each other, southern KwaZulu-Natal (unprotected) was not grouped with Mkambati (protected). Southern KwaZulu-Natal was rather grouped with northern KwaZulu-Natal (unprotected) due to the differences in conservation status between the sites. 
and has a low anthropogenic impact (Lasiak, 1998; Emmerson \& Philip, 2004). The high rocky shore to sandy beach ratio in the reserve ensures that seafood stocks are relatively abundant, with the rock platforms exposed to strong wave action (Fielding et al., 1994; Lasiak, 1998). The area also comprises good vegetation cover in the form of coastal forests, thornveld, grasslands and Pondoland sourveld (Acocks, 1998). The mean annual rainfall in the area is above $1100 \mathrm{~mm}$ and the mean annual sea temperature is $20.5^{\circ} \mathrm{C}$ (Plumstead, Prinsloo \& Schoonbee, 1991). While Mkambati is situated in relative close proximity to the southernmost KZN Coast sites, we expected that the conservation status of the reserve and associated differences in land use (e.g. only limited recreational fishing is allowed in the reserve) would result in substantial differences in prey availability for otters.

\section{Tsitsikamma}

Tsitsikamma National Park (TS) is situated on the southern coast of the Eastern and Western Cape Provinces with the two Groot Rivers forming the boundary of the park (Arden-Clarke, 1986). The park consists of five large rivers in deep gorges as well as many small rivers and streams that flow over the escarpment. The majority of the coastline is made up of rocky shores with less than $2 \%$ being made up of sandy beaches, and is characterized by high invertebrate population densities (Arden-Clarke, 1986). The area has a mild climate and receives an average rainfall of $900 \mathrm{~mm}$ (Arden-Clarke, 1986). The mean ocean temperature in summer is $19.07^{\circ} \mathrm{C}$ (Schumann et al., 1995). Vegetation in the area is generally made up of dry afromontane forest, dry scrub forest and mountain fynbos (Hanekom, Southwood \& Ferguson, 1989).

\section{Spraint collection and analysis}

At each site, we searched coastal rocky shores for latrines and spraints in the area between the high tide mark and the start of vegetation. This area was traversed once during each sampling period. Latrines and spraints were identified through their shape, size and characteristic odour and were confirmed by the presence of tracks and signs, where applicable, characteristic of $A$. capensis (Stuart \& Stuart, 2013). Scats belonging to water mongoose (Atilax paludinosus) were identified by their smaller size as well as by the presence of black and white banded hairs within the scat and were not collected. Relatively fresh and intact spraints belonging to $A$. capensis were collected and stored in labelled bags. Spraint collection took place over two field trips with the first during late summer (March/April) and the second during winter (June/July) in 2014. These spraints roughly represented the period from December/January (2013/2014) to March/April (summer) and April/ May to June/July (winter), respectively. Two of us (R.K.J. and T.M.) collected spraints in the first (summer) field trip, and one (R.K.J.) in the second (winter) field trip.

Collected spraints were dried in an oven (ULM 500 220V, Memmert, Schwabach, Germany) at $40^{\circ} \mathrm{C}$ for approximately 24 hours. The dried spraints were then weighed to the nearest $0.01 \mathrm{~g}$ with an electric pioneer balance (PA2102C, Ohaus Corp., Pine Brook, NJ, U.S.A.). Spraints were then carefully sorted into main prey categories namely lobster, fish, crab, mollusc, octopus and 'other' (which included mammal bones, insect exoskeletons, reptile skin and unidentified objects). These categories were subsequently weighed to the nearest $0.01 \mathrm{~g}$. The remains within the prey categories were visually identified to the lowest possible taxonomic level, based on standard references (e.g. Emmerson \& Philip, 2004). One researcher (R.K.J.) was responsible for the sorting and analysis of all of the spraints collected.

\section{Data analysis}

The 'percentage of occurrence' (PO) of individual prey categories and the 'relative percentage of occurrence' (RPO) for all prey categories were calculated using the following equations:

$$
\begin{gathered}
\mathrm{PO}=\frac{\begin{array}{l}
\text { Number of spraints containing } \\
\text { a specific prey category }
\end{array}}{\text { Total number of spraints }} \times 100 \\
\mathrm{RPO}=\frac{\begin{array}{l}
\text { Total number of occurrences of a } \\
\text { specific prey category in all spraints }
\end{array}}{\begin{array}{l}
\text { Total number of occureences of all } \\
\text { prey categories in all spraints }
\end{array}} \times 100
\end{gathered}
$$

Also, the 'percentage dry mass' (PDM) of prey remains in each spraint was determined for each location and season. PDM is the dry mass of a prey category relative to the dry mass of the spraint. PO ranks the occurrence of various prey items, rather than indicating the relative quantities in the diet (Carss \& Parkinson, 1996), often resulting in the underestimation of prey taken in large quantities (Englund, 1965; Jenkins, Walker \& McCowan, 1979) but can account for rare food items leading 
to a better understanding of a carnivore's ecology, such as its role as an opportunist or specialist (Klare, Kamler \& MacDonald, 2011). The PDM of food remains as an estimate of importance is also limiting, since it favours prey species that are made up of large amounts of indigestible material such as crustaceans, whilst prey made up mostly of soft tissue are under-represented (Somers, 2000; Emmerson \& Philip, 2004). While not independent of each other, we used both these methods in combination to increase the overall confidence in our results.

We used the $R$ programming environment ${ }^{\circledR}(R$ Core Team, 2014) to investigate differences between sites and seasons per prey category. PDM data of each prey category were subjected to a Kruskal-Wallis test (KW), followed by Nemenyi post hoc tests (package 'PMCMR'; Pohlert, 2014) to determine where significant differences between pairs of sites or seasons occurred. Overall inter-site variation in PO data was investigated using Chi-square tests of association, whilst differences between sites and season pairs were investigated using Chi-square tests of association with Yates' correction.

\section{RESULTS}

Overall, 309 Cape clawless otter spraints were collected from 75 different latrines, with 116 (36 latrines) collected during the summer and 193 (39 latrines) during the winter (see Fig. 2 for sitespecific seasonal sample sizes). Identified crab species included shore crab (Cyclograpsus punctatus), Cape rock crab (Plagusia chabrus), Natal rock crab (Grapsus grapsus tenuicrustatus), green rock crab (Grapsus fourmanouri), Potamonautes sp., and Thalamita sp. The prey category 'lobster' was made up of one species at each site, namely the East Coast rock lobster (Panulirus homarus) in MK and the KZN Coast, and the Cape lobster (Jasus lalandii) in TS. 'Fish' comprised mostly unidentified fish due to the absence of otoliths, as well as readily identifiable rock sucker (Chorisochismus dentex), while 'mollusc' comprised unidentifiable limpets, mussels and other molluscs. 'Octopus' was made up of unidentifiable octopus and 'other' comprised a variety of food items including ungulate dung, insects, small mammals and reptiles.

\section{Spraint composition: RPO and PO of prey categories}

Based on RPO, lobster formed the dominant prey category in MK (summer: $37 \%$, winter: $36 \%$ ), while crab was the dominant prey category in TS (summer: $55 \%$, winter: $50 \%$ ) with no variation in dominance occurring between seasons at either of these two sites. The KZN Coast was dominated by two prey categories with no seasonal variation in dominance: crab (summer: $37 \%$, winter: $41 \%$ ) and fish (summer: $35 \%$, winter: $34 \%$ ) (Fig. 2).

Overall, the $\mathrm{PO}$ of crab in spraints was not significantly different between sites $\left(\chi^{2}=2.12\right.$, d.f. $=2, P$ $>0.05$ ) (Fig. 3a). However, the following site/season pairs were significantly different from each other:

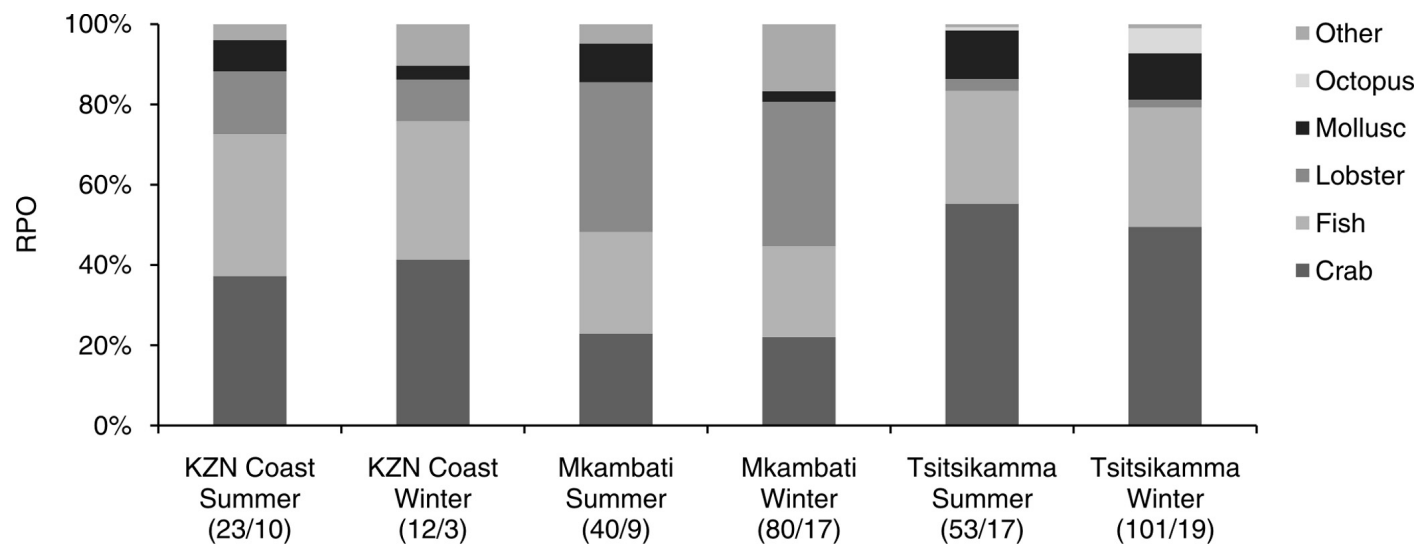

SITE AND SEASON

Fig. 2. Bar graph showing the relative percentage of occurrence (RPO) of prey categories detected in a total of 309 Cape clawless otter (Aonyx capensis) spraints collected on the eastern and southern coastline of southern Africa. The number of spraints and latrines for each site and season is given in brackets (number of spraints/number of latrines). Prey categories are indicated in the legend. 

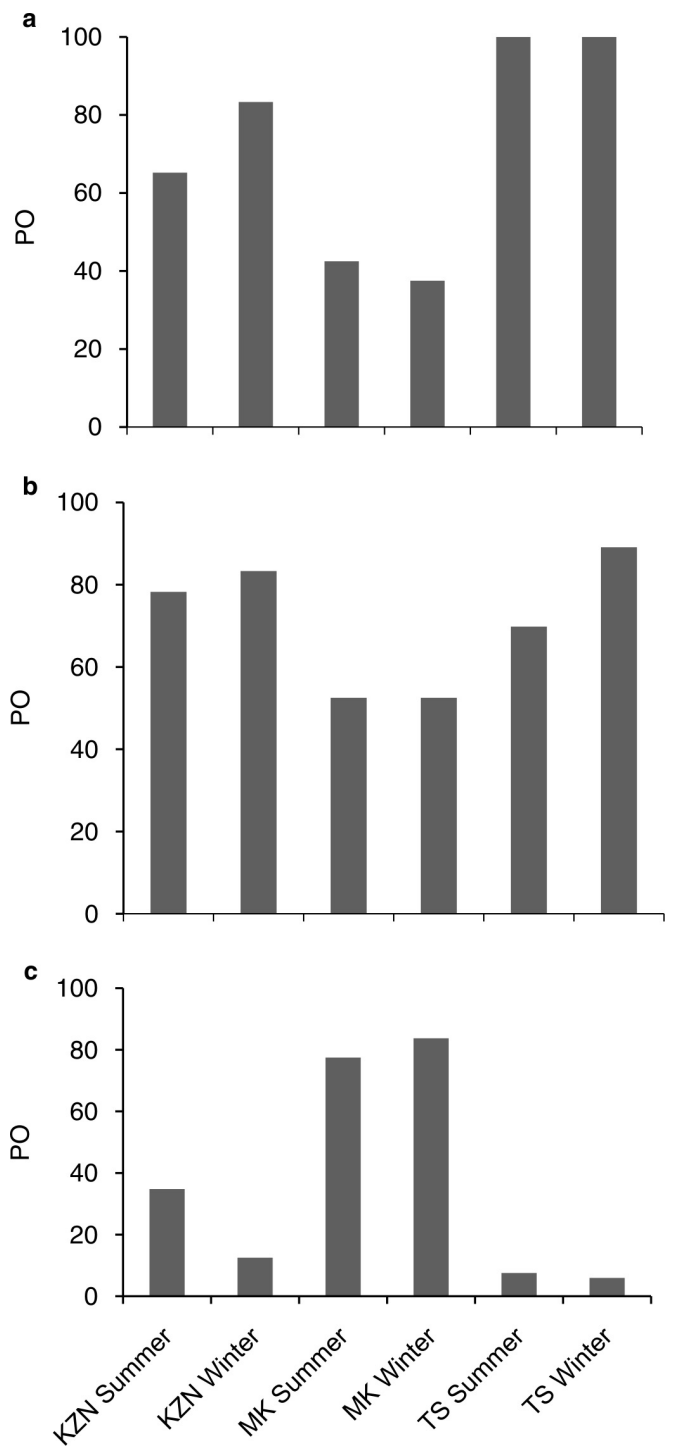

Fig. 3. Bar graph showing the percentage of Cape clawless otter spraints collected where (a) crab, (b) fish and (c) lobster were present (percentage of occurrence, $\mathrm{PO}) . \mathrm{KZN}=\mathrm{K}$ waZulu-Natal Coast, $\mathrm{MK}=$ Mkambati, TS = Tsitsikamma.

$$
\begin{aligned}
& \mathrm{MK}_{\text {winter }}-\mathrm{TS}_{\text {winter }}, \mathrm{MK}_{\text {summer }}-\mathrm{TS}_{\text {summer }}, \mathrm{KZN}_{\text {summer }}-\mathrm{MK}_{\text {summer}} \text {, } \\
& \mathrm{KZN}_{\text {summer }}-\mathrm{TS}_{\text {summer, }} \mathrm{KZN}_{\text {winter }}-\mathrm{MK}_{\text {winter, }} \mathrm{TS}_{\text {summer }}-\mathrm{MK}_{\text {winter }} \text { and } \\
& \mathrm{TS}_{\text {winter }}-\mathrm{MK}_{\text {summer. }}(P<0.05 \text { in all cases }) \text {. }
\end{aligned}
$$

The $\mathrm{PO}$ of fish in spraints was also not significantly different between sites $\chi^{2}=1.11$, d.f. $=2$, $P>0.05)$. However, there were significant differences between the following site/season pairs:

$\mathrm{MK}_{\text {winter }}-\mathrm{TS}_{\text {winter }}, \mathrm{KZN}_{\text {summer }}-\mathrm{MK}_{\text {summer }}$ and $\mathrm{KZN}_{\text {winter }}-\mathrm{MK}_{\text {winter, }}$ $(P<0.05$ in all cases) (Fig. 3b).
The PO of lobster in spraints was significantly different $\left(\chi^{2}=9.59\right.$, d.f. $=2, P<0.05$ ) (Fig. 3c) with significant differences occurring between:

$\mathrm{MK}_{\text {winter }}-\mathrm{TS}_{\text {winter }}, \mathrm{MK}_{\text {summer }}-\mathrm{TS}_{\text {summer }}, \mathrm{KZN}_{\text {summer }}-\mathrm{MK}_{\text {summer }}$,
$\mathrm{KZN}_{\text {winter }}-\mathrm{MK}_{\text {winter, }}, \mathrm{KZN}_{\text {summer }}-\mathrm{TS}_{\text {summer }}, \mathrm{MK}_{\text {winter }}-\mathrm{TS}_{\text {summer }}$ and
$\mathrm{MK}_{\text {summer }}-\mathrm{TS}_{\text {winter }}(P<0.05$ in all cases $)$.

At a species level, the PO of Cape rock crab was significantly different between:

$$
\begin{aligned}
& \mathrm{TS}_{\text {winter }}-\mathrm{MK}_{\text {winter }} ; \mathrm{TS}_{\text {summer }}-\mathrm{MK}_{\text {summer }} ; \mathrm{TS}_{\text {summer }}-\mathrm{KZN}_{\text {summer }} \text {; } \\
& \mathrm{TS}_{\text {winter }}-\mathrm{KZN}_{\text {winter }} ; \mathrm{TS}_{\text {summer }}-\mathrm{MK}_{\text {winter }} ; \mathrm{TS}_{\text {winter }}-\mathrm{MK}_{\text {summer }} \text { and } \\
& \mathrm{TS}_{\text {winter }}-\mathrm{KZN}_{\text {summer }}(P<0.05 \text { in all cases }) \text { (Fig. 4). }
\end{aligned}
$$

The $\mathrm{PO}$ of shore crab was significantly different between:

$\mathrm{KZN}_{\text {summer }}-\mathrm{TS}_{\text {summer }}, \mathrm{MK}_{\text {summer }}-\mathrm{TS}_{\text {summer }}, \mathrm{KZN}_{\text {summer }}-\mathrm{MK}_{\text {summer }}$,
$\mathrm{KZN}_{\text {winter }}-\mathrm{MK}_{\text {winter, }} \mathrm{KZN}_{\text {summer }}-\mathrm{TS}_{\text {summer }}$ and $\mathrm{TS}_{\text {summer }}-\mathrm{MK}_{\text {winter }}$ $(P<0.05$ in all cases).

Rock sucker made up $9.5 \%$ of the fish in MK in winter ( $0 \%$ in summer), whilst in TS its contribution amounted to $21.6 \%$ and $38.9 \%$ in summer and winter, respectively.

A summary of the $\mathrm{PO}$ of all the remaining prey groups is presented in Table 1. The chi-square tests of association with Yates' correction indicated no significant differences between and within sites for all seasons and for all the species listed in the table, with the exception of the Cape rock crab and shore crab.

\section{Spraint composition: PDM of prey categories}

There was significant inter-site variation in the overall PDM of individual prey categories, while some seasonal differences were also evident (Fig. 5). Lobster formed the dominant prey category by PDM in MK (summer: $69 \%$, winter: $78 \%$ ), while crab was the dominant prey category in TS (summer: $80 \%$, winter: $81 \%$ ). The KZN Coast was dominated by three prey categories with dominance varying between seasons: crab (summer: 67\%, winter: $35 \%$ ), fish (summer: $7 \%$, winter: $45 \%$ ) and lobster (summer: 26\%, winter: 18\%) (Fig. 5).

The PDM contributions of crab, fish and lobster were significantly different between sites and seasons. Accordingly, the PDM contributions of crab were statistically different $(H=137.42$, d.f. $=5, P<0.05$; Fig. 6 a) with significant differences occurring between:

$$
\begin{aligned}
& \mathrm{MK}_{\text {winter }}-\mathrm{TS}_{\text {winter }}, \mathrm{MK}_{\text {summer }}-\mathrm{TS}_{\text {summer, }}, \mathrm{TS}_{\text {winter }}-\mathrm{KZN}_{\text {winter }} \text {, } \\
& \mathrm{MK}_{\text {summer }}-\mathrm{KZN}_{\text {summer }} \mathrm{TS}_{\text {summer }}-\mathrm{MK}_{\text {winter, }} \mathrm{TS}_{\text {winter }}-\mathrm{MK}_{\text {summer }} \\
& \mathrm{TS}_{\text {summer }}-\mathrm{KZN}_{\text {winter }} \text { and } \mathrm{KZN}_{\text {summer }}-\mathrm{MK}_{\text {winter }}(P<0.05 \text { in all } \\
& \text { cases). }
\end{aligned}
$$




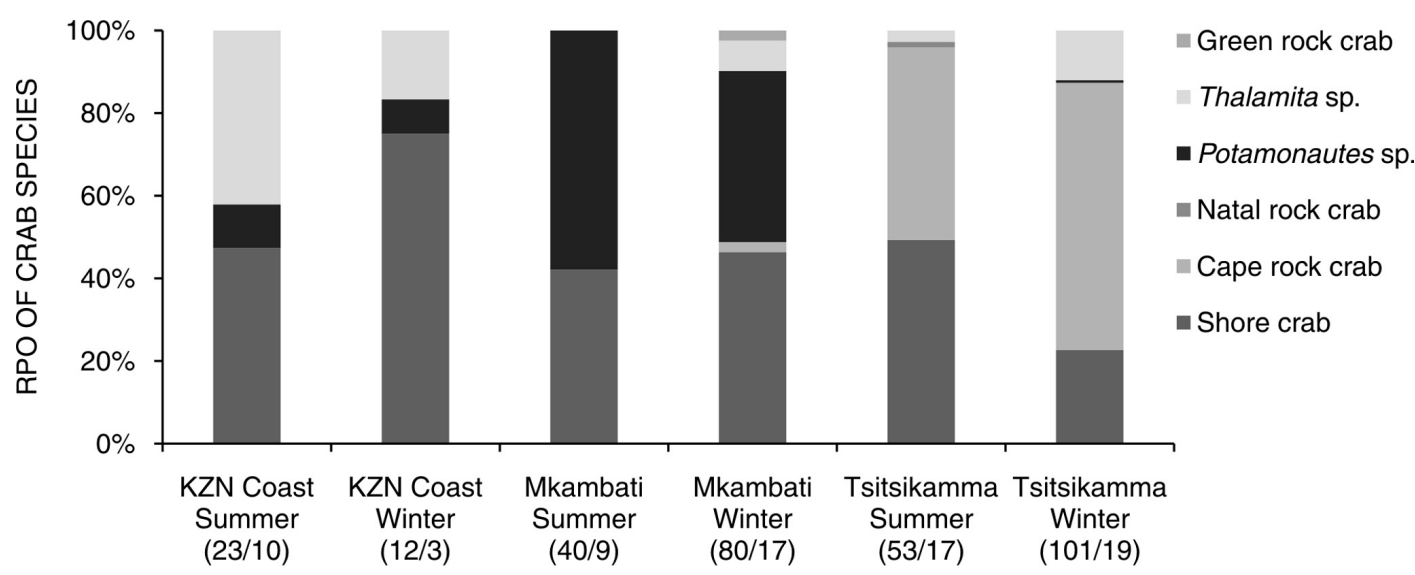

SITE AND SEASON

Fig. 4. Bar graph showing the relative percentage of occurrence (RPO) of each crab species. This represents the total number of occurrences of a specific crab species detected in all spraints relative to the total number of occurrences of all crab species detected in a total of 309 Cape clawless otter spraints collected on the eastern and southern coastline of southern Africa. The number of spraints and latrines for each site and season is given in brackets (number of spraints/number of latrines). Crab species are indicated in the legend.

The PDM contributions of fish were also statistically different $(H=40.08$, d.f. $=5, P<0.05$; Fig. $6 \mathrm{~b})$ with significant differences occurring between:

$\mathrm{TS}_{\text {winter }}-\mathrm{MK}_{\text {winter }}, \mathrm{KZN_{ \text {winter } }}-\mathrm{MK}_{\text {winter }}, \mathrm{TS}_{\text {summer }}-\mathrm{MK}_{\text {winter }}, \mathrm{TS}_{\text {winter }}$ $-\mathrm{MK}_{\text {summer }}$ and $\mathrm{KZN}_{\text {winter }}-\mathrm{MK}_{\text {summer }}(P<0.05$ in all cases $)$.

Finally, the PDM contributions of lobster were significantly different $(H=170.78$, d.f. $=5, P<0.05$; Fig. 6c) between the following site/season combinations:

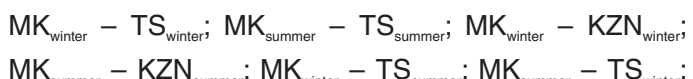

$\mathrm{MK}_{\text {winter }}-\mathrm{KZN}_{\text {summer }} ; \mathrm{MK}_{\text {summer }}-\mathrm{KZN}_{\text {winter }}(P<0.05$ in all cases).

\section{DISCUSSION}

A central aim of our study was to assess and compare the diet of Cape clawless otters from three different areas along the South African eastern and southern coastline. We collected more spraints during winter, compared to summer, at both MK and TS, despite collection effort being similar. These differences may be associated with increases in experience of the spraint collectors, but we consider it plausible that otter activity along

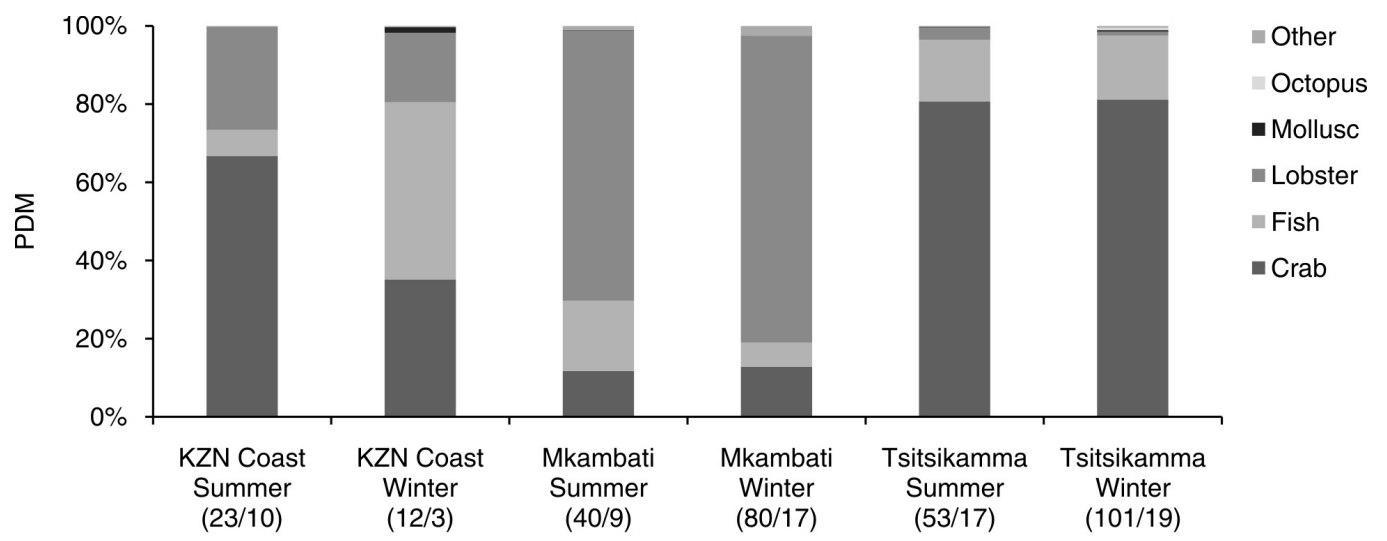

SITE AND SEASON

Fig. 5. Bar graph showing the percentage dry mass (PDM) of each prey category detected in a total of 309 Cape clawless otter spraints collected on the eastern and southern coastline of southern Africa. The number of spraints and latrines for each site and season is given in brackets (number of spraints/number of latrines). Prey categories are indicated in the legend. 


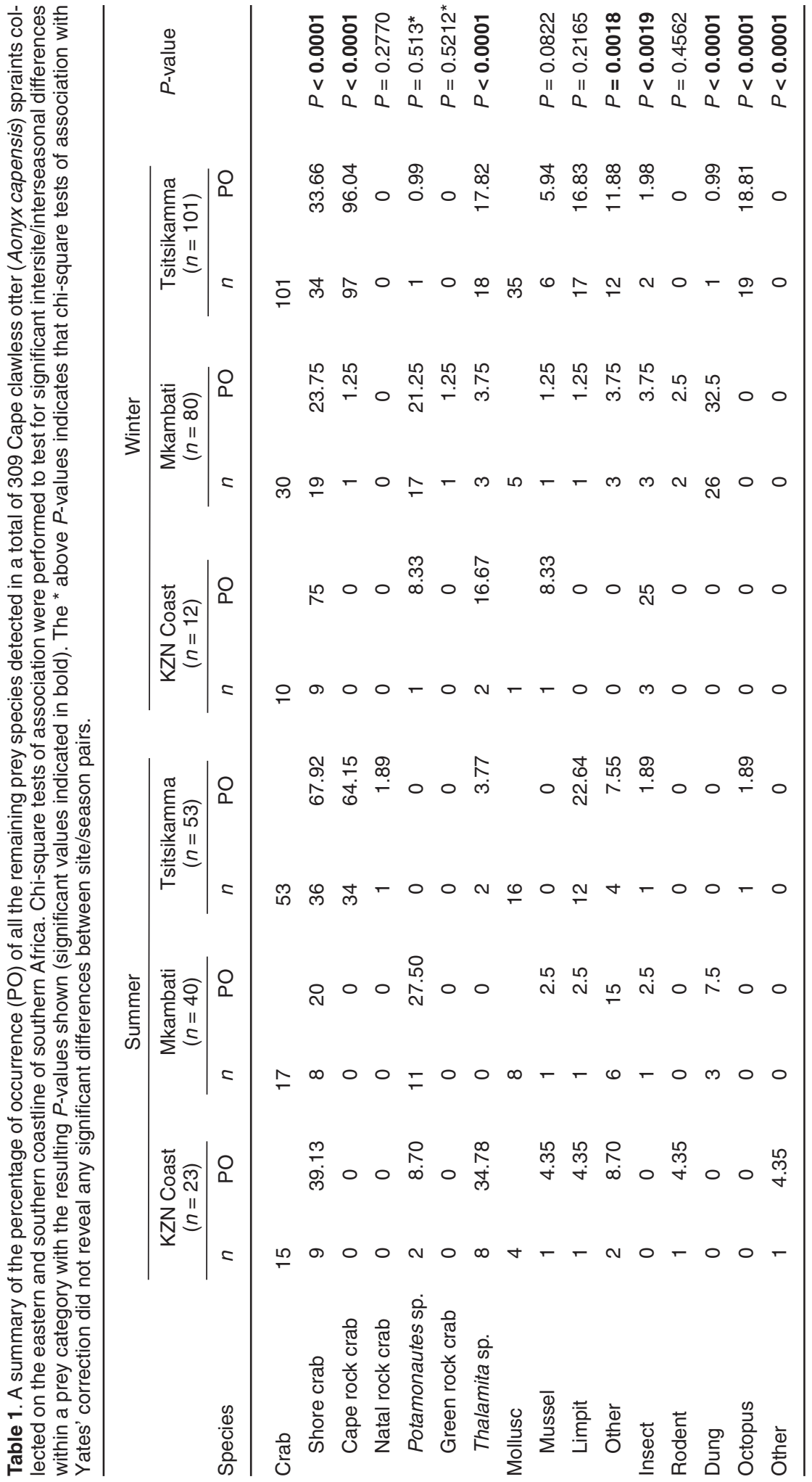



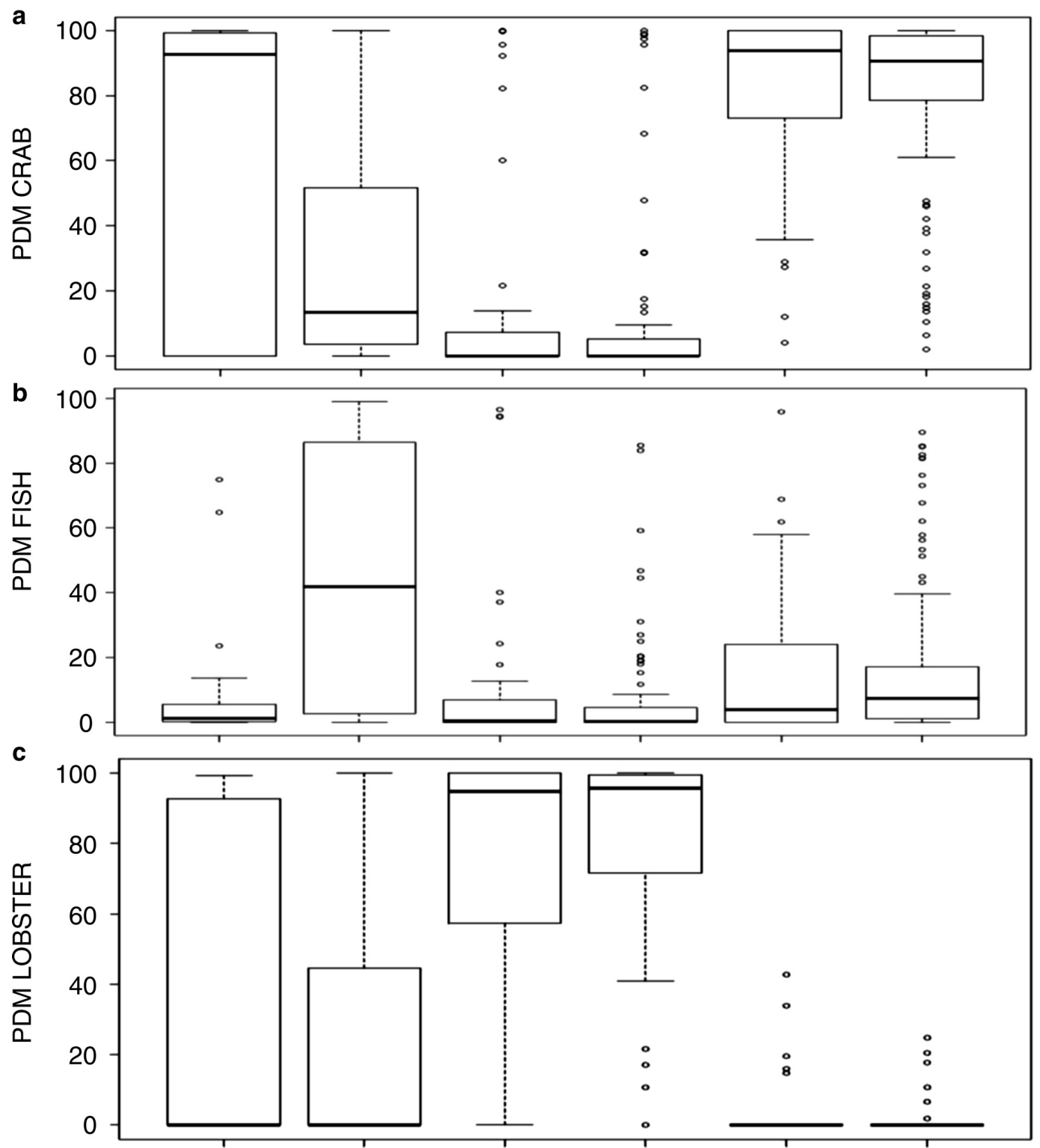

KZN Coast: KZN Coast: Mkambati: Mkambati: Tsitsikamma: Tsitsikamma: Summer Winter Summer Winter Summer Winter

Fig. 6. Box plot diagrams showing the percentage dry mass (PDM) of (a) crab, (b) fish and (c) lobster detected in a total of 309 Cape clawless otter spraints collected on the eastern and southern coastline of southern Africa. The thick lines within boxes represent the median, upper lines represent the upper quartile and lower lines the lower quartile. Dotted lines on either side of the upper and lower quartiles represent 1.5 times the interquartile range. Outliers are represented by empty circles.

the coast increased during winter months. Winter is potentially a time when family groups are at their largest following the weaning of pups (Verwoerd, 1987), which results in more individuals foraging within the same area. However, the reproductive cycle of Cape clawless otters is not well known (Larivière, 2001), and appears to be quite variable, suggesting that other unknown factors may contribute to increased activity during winter.

The PO and PDM results show that, for all three 
sites, the diet of Cape clawless otter is made up mostly of prey belonging to two groups, one of which is dominant at each site. The dominant prey group varies between sites, but not between seasons at all three sites. Lobster is the dominant prey item in MK, whereas crab is the dominant prey category in TS and the KZN Coast. Fish is the second most important prey category at all sites. The East Coast rock lobster is the species of lobster of most importance in MK, whilst the shore crab and Cape rock crab are the crab species of most importance in TS. The shore crab is the crab species of most importance along the KZN Coast. When comparing sites, there is significantly more crab taken in TS, compared to MK during both seasons and the KZN Coast during winter, while more lobster is taken in MK compared to TS and the KZN Coast during both seasons.

The differences in diet and important prey items between sites may be attributed to many factors such as differences in water temperature, climate, human disturbance, coastal topographies, the presence or absence of kelp beds at sites (Verwoerd, 1987), as well as influences of prey selection (Somers, 2000). However, variation in diet between sites is likely principally caused by differences in prey availability and abundance, rather than preference of certain prey types as was found in the North American river otter (Lontra canadensis) (Day, Westover \& McMillan, 2015). For example, lobster, the seemingly most important prey item at MK, is found in high densities $\left(0.1\right.$ lobster $\left./ \mathrm{m}^{2}\right)$ in MK compared to areas along the coastline around the reserve (Fielding et al., 1994). Similar conclusions were reached by Emmerson \& Philip (2004) in their study on the diet of Cape clawless otters at two sites in the Wild Coast area of the Eastern Cape, including MK.

Although geographically close to MK, KZN differs in terms of land use and conservation status, likely resulting in the recorded differences in diet of otters foraging along this zone. By comparing $\mathrm{KZN}$ to MK we ultimately show the potential influence that anthropogenic effects may have on prey availability and how effective protected areas are in protecting prey species available to otters. This is illustrated by the differences in lobster consumption by otters between KZN and MK, implying that lobsters are more abundant in MK and less abundant in KZN, conceivably due to the limitation on human harvesting of lobster in MK. Additional likely influences on diet include the effect of water temperature on the mobility of fish. Fish are thought to be more vulnerable, and easier to catch in colder water (Rowe-Rowe, 1975), potentially explaining the reason for the significantly greater fish predation in TS, compared to MK in winter. In addition, our results provide support for the 'locomotor crossover hypothesis' which states that active predators will most likely predate on sedentary prey (DiRienzo, Pruitt \& Hedrick 2013; Sweeney et al., 2013), explained by the higher encounter rate that active predators experience with sedentary prey compared to the lower encounter rate of active prey. This hypothesis is supported by the higher consumption of crustaceans, which are relatively sedentary, as well as predation on sedentary rock sucker fish. The presence of other (unknown) fish species in the diet is not necessarily contrary to this hypothesis, since otters are known to often target benthic fish species (Somers, 2000), many of which are sit-and-wait predators or slow-moving species.

Earlier studies suggested that the diet of otters at MK was dominated by lobster followed by fish, crab and molluscs (Emmerson \& Philip, 2004), while the diet of otters at TS was found to be dominated by crab, specifically Cape rock crab, followed by fish (mainly $C$. dentex) and octopus (Octopus granulatus) (van der Zee, 1981; Arden-Clarke, 1983). Our results for both sites are generally similar, with some minor differences. For example, we found ungulate dung in substantial proportions of otter spraints $(7.5 \%$ occurrence in summer and $32.5 \%$ occurrence in winter) at MK. The reason for eating ungulate dung is unknown but has been linked to possible incidental ingestion whilst feeding on dung beetles or other invertebrates (Somers \& Nel, 2003). No record of this dietary component has been found for any species of otter other than A. capensis (Rowe-Rowe, 1977a; Somers \& Nel, 2003). With the main components of the diet not varying between seasons at MK, it is not known why there was an increase in the consumption of ungulate dung during the winter months. One possible explanation is that ungulates frequent the area around the coast more during winter, therefore increasing the amount of dung available (R.K. Jordaan, pers. obs.).

In TS, differences in diet found in previous studies include the level of importance of octopus and the high proportion of $C$. dentex in the diet. The presence of octopus in spraints is not easily determined and therefore the most likely reason for the low level of importance of octopus in this study. The proportion of fish made up of $C$. dentex is 
lower in this study compared to that of van der Zee (1981). The overall similarity of our results with those of van der Zee (1981), Arden-Clarke (1983) and Emmerson \& Philip (2004) suggests that the diet of the otters at TS and MK remained relatively stable over recent years.

The methods we used to obtain basic dietary estimates are used widely in carnivore research (e.g. Putman, 1984; Makhado et al., 2013) as well as in other otter species, including Eurasian otter (Lutra lutra; Clode \& MacDonald, 1995; Gorgadze, 2013; Juhász et al., 2014), sea otter (Enhydra lutris; Watt, Siniff \& Estes, 2000), giant otter (Pteronura brasiliensis; Silva, Rosas \& Zuanon, 2014) and Neotropical otter (Lontra longicaudis; Quadros \& Monteiro-Filho, 2001). Despite this method being widely used, the constraints associated with this method (i.e. the reliance on hard prey remains) remain (e.g. Dellinger \& Trillmich, 1988). We were able to collect a relatively small number of spraints along the KZN Coast, compared to large numbers at MK and TS, further limiting the inferences of our dietary assumptions at this site. Furthermore, we were unable to reconstitute estimates of biomass ingested by otters, since prey remains were generally too fragmented to make estimates on actual numbers of prey items and/or the size of ingested prey items. Future assessments of the trophic ecology of Cape clawless otters should preferably include other methods previously used to infer diet in otters such as visual observations (Kruuk, Conroy \& Moorhouse, 1987; Somers, 2000), stomach content analysis (Erlinge \& Jenson, 1981; Skarén, 1992), stable isotopes (Newsome et al., 2009, 2010) and bio-logging approaches (Tinker et al., 2007). Continued dietary assessments are potentially very important in order to evaluate likely impacts associated with changes in prey abundance and distribution related to warming oceans (e.g. Figueira \& Booth, 2010). For example, fish are expected to show spatial (both horizontal and vertical) shifts in distribution associated with changes in temperature regimes (Perry et al., 2005), potentially forcing their predators to alter their diets and/or foraging strategies.

In conclusion, our results suggest that Cape clawless otters display substantial spatial variation in their marine diets, and are likely able to take advantage of the localized prey that is available to them. We suggest that there is little temporal variation in diet, both between seasons, as well as long-term when comparing our results with earlier reports from TS and MK. Such stability in diet over time means that Cape clawless otter diet monitoring could potentially provide some useful information on the status of shoreline communities where otters forage.

\section{ACKNOWLEDGEMENTS}

Permits were granted by the Eastern Cape Parks and Tourism Agency for the collection of material in Mkambati Nature Reserve (RA0172) and South African National Parks (SANParks) for material collection in the Garden Route National Park. Financial support was provided by the South African Department of Science and Technology through the National Research Foundation, and by a University of Pretoria Research Development Program grant (T. McIntyre). We are grateful for the comments provided by D.M. Parker and E. Do Linh San, as well as one anonymous reviewer.

\section{REFERENCES}

Acocks, J.P.H. (1988). Veld types of South Africa (3rd edn). Memoirs of the Botanical Survey of South Africa, 57, 1-146.

Arden-Clarke, C.H.G. (1983). Population density and social organisation of the Cape clawless otter, Aonyx capensis Schinz, in the Tsitsikamma Coastal National Park. (Unpublished M.Sc. thesis). Pretoria, South Africa: University of Pretoria.

Arden-Clarke, C.H.G. (1986). Population density, home range size and spatial organization of the Cape clawless otter, Aonyx capensis, in a marine habitat. Journal of Zoology, London, 209, 201-221.

Bentall, G.B. (2005). Morphological and behavioural correlates of population status in the Southern Sea otter: a comparative study between central California and San Nicolas Island. (Unpublished M.Sc. thesis). Santa Cruz, U.S.A.: University of California.

Branch, G.M. \& Branch, M. (1981). The living shores of southern Africa. Cape Town, South Africa: C. Struik.

Bustamante, R.H. \& Branch, G.M. (1996). Large scale patterns and trophic structure of southern African rocky shores: the roles of geographic variation and wave exposure. Journal of Biogeography, 23(3), 339-351.

Carss, D.N. \& Parkinson, S.G. (1996). Errors associated with otter Lutra lutra faecal analysis. Assessing general diet from spraints. Journal of Zoology, London, 238, 301-317.

Clode, D. \& MacDonald, D.W. (1995). Evidence for food competition between mink (Mustela vison) and otter (Lutra zutra) on Scottish islands. Journal of Zoology, London, 237, 435-444.

Day, C.C., Westover, M.D. \& McMillan, B.R. (2015). Seasonal diet of the northern river otter (Lontra canadensis): what drives prey selection? Canadian Journal of Zoology, 93, 197-205.

Dellinger, T. \& Trillmich, F. (1988). Estimating diet composition from scat analysis in otariid seals (Otariidae): is it reliable? Canadian Journal of Zoology 66(8), 1865-1870. 
DiRienzo, N., Pruitt, J.N. \& Hedrick, A.V. (2013). The combined behavioural tendencies of predator and prey mediate the outcome of their interaction. Animal Behaviour, 86(2), 317-322.

Emmerson, W. \& Philip, S. (2004). Diets of Cape clawless otters at two South African coastal localities. African Zoology, 39(2), 201-210.

Englund, J. (1965). Studies on the food ecology of the red fox (Vulpes vulpes) in Sweden. Viltrevy, 3, 377-484.

Erlinge, S. \& Jensen, B. (1981). The diet of otters (Lutra lutra L.) in Denmark. Natura Jutlandica, 19, 161-165.

Field, J.G. \& Griffiths, C.L. (1991). Littoral and sub littoral ecosystems of southern Africa. Ecosystems of the World. In A.C. Matheson and P.H. Nienhuis (Ed.), Intertidal and littoral ecosystems (pp. 323-346). Amsterdam, Netherlands: Elsevier Science Publisher.

Fielding, P.J., Robertson, W.D., Dye, A.H., Tomalin, B.J., Vanderelst, R.P., Beckley, L.E., Mann, B.Q., Birnie, S., Schleyer, M.H. \& Lasiak, T.A. (1994). Transkei coastal fisheries resources. Oceanographic Research Institute Special Publication, No. 3.

Figueira, W.F. \& Booth, D.J. (2010). Increasing ocean temperatures allow tropical fishes survive overwinter in temperate waters. Global Change Biology, 16, 506-516.

Gorgadze, G. (2013). Seasonal diet of the otter (Lutra lutra) on the Alazani River (Georgia). Hystrix, the Italian Journal of Mammalogy, 24(2), 157-160.

Hanekom, N., Southwood, A. \& Ferguson, M. (1989). A vegetation survey of the Tsitsikamma Coastal National Park. Koedoe, 32(1), 47-67.

Harris, T.F.W., Jordaan, J.M., McMurray, W.R., Verwey, C.I. \& Anderson, F.P. (1962). Mixing in the surf zone. In International conference on water pollution research (pp. 117-198). London, U.K.: Pergamon Press.

Jenkins, D., Walker, J.G.W. \& McCowan, D. (1979). Analysis of otter (Lutra lutra) faeces from Deeside, N.E. Scotland. Journal of Zoology, London, 187, 235-244.

Juhász, K., Végvári, Z., Perpék, M., Lukács, B.A. \& Nagy, S.A. (2014). Main versus alternative prey of Eurasian otters in an East-European artificial wetland system. North-Western Journal of Zoology, London, 10(1), $1-9$.

Klare, U., Kamler, J.F. \& Macdonald, D.W. (2011). A comparison and critique of different scat-analysis methods for determining carnivore diet. Mammal Review, 41(4): 294-312.

Kruuk, H., Conroy, J.W.H. \& Moorhouse, A. (1987). Seasonal reproduction, mortality and food of otters (Lutra lutra L.) in Shetland. Symposia of the Zoological Society of London, 58, 263-278.

Lasiak, T.A. (1998). Multivariate comparisons of rocky infratidal macrofaunal assemblages from replicate exploited and non-exploited localities on the Transkei coast of South Africa. Marine Ecology Progress Series, 167, 15-23.

Larivière, S. (2001). Aonyx capensis. Mammalian Species, 671, 1-6.

Makhado, A.B., Bester, M.N., Somhlaba, S. \& Crawford, R.J.M. (2013). The diet of the subantarctic fur seal, Arctocephalus tropicalis, at Marion Island. Polar Biology, 36, 1609-1617.
Nel, J.A.J. \& Somers, M.J. (2002). The status of otters in Africa: an assessment. In R. Dulfer, J. Conroy, J.A.J. Nel \& A.C. Gutleb (Eds), Otter conservation - An example for a sustainable use of wetlands (pp. 258-266). Proceedings of the VIlth International Otter Symposium, IUCN Otter Specialist Group Bulletin Vol. 19A (Special Issue).

Nel, J.A.J. \& Somers, M.J. (2007). Distribution and habitat choice of Cape clawless otters, Aonyx capensis, in South Africa. South African Journal of Wildlife Research, 37, 61-70.

Newsome, S.D., Tinker, M.T., Monson, D.H., Oftedal, O.T., Ralls, K., Staedler, M.M., Fogel, M.L. \& Estes, J.A. (2009). Using stable isotopes to investigate individual diet specialization in California sea otters (Enhydra lutris nereis). Ecology, 90(4), 961-974.

Newsome, S.D., Bentall, G.B., Tinker, M.T., Oftedal, O.T., Ralls, K., Estes, J.A.\& Fogel, M.L. (2010). Variation in d13C and d15N diet-vibrissae trophic discrimination factors in a wild population of California sea otters. Ecological Applications, 20(6), 1744-1752.

Perry, A.L., Low, P.J., Ellis, J.R. \& Reynolds, J.D. (2005). Climate change and distribution shifts in marine fishes. Science, 308, 1912-1915.

Plumstead, E.E., Prinsloo, J.F. \& Schoonbee, H.J. (1991). A survey of the fish fauna of Transkei estuaries. Part Four: The Mntafufu and Mzamba River estuaries. South African Journal of Zoology, 26, 153163.

Pohlert, T. (2014). The Pairwise Multiple Comparison of Mean Ranks Package (PMCMR). R. package. https://cran.r-project.org/web/packages/

Putman, R.J. (1984). Facts from faeces. Mammal Review, 14, 79-97.

Quadros, J. \& Monteiro-Filho, E.L.A. (2001). Diet of the Neotropical otter, Lontra longicaudis, in an Atlantic forest area, Santa Catarina State, southern Brazil. Studies on Neotropical Fauna and Environment, 36(1), 15-21.

R Core Team. (2014). R: A language and environment for statistical computing. R Foundation for Statistical Computing, Vienna, Austria. https://www.r-project.org/foundation/board.html

Rowe-Rowe, D.T. (1975). Biology of Natal mustelids. (Unpublished M.Sc. thesis). Durban, South Africa: University of Natal.

Rowe-Rowe, D.T. (1977a). Food ecology of otters in Natal, South Africa. Oikos, 28, 210-219.

Rowe-Rowe, D.T. (1977b). Prey capture and feeding behaviour of South African otters. Lammergeyer, 23, 13-21.

Rowe-Rowe, D.T. \& Somers, M.J. (1998). Diet, foraging behaviour and coexistence of African otters and the water mongoose. Symposium of the Zoological Society of London, 71, 215-227.

Silva, R.E., Rosas, F.C.W. \& Zuanon, J. (2014). Feeding ecology of the Giant otter (Pteronura brasiliensis) and the Neotropical otter (Lontra longicaudis) in Jau National Park, Amazon, Brazil. Natural History, 48, 465-479.

Skarén, U. (1997). Analysis of one hundred otters killed by accidents in central Finland. IUCN Otter Specialist Group Bulletin, 7, 9-12. 
Somers, M.J. (2000). Seasonal variation in the diet of Cape clawless otters (Aonyx capensis) in a marine habitat. African Zoology, 35, 261-268.

Somers, M.J. \& Nel, J.A.J. (2003). Diet in relation to prey of Cape clawless otters in two South African rivers. African Zoology, 38, 317-326.

Stuart, C. \& Stuart, M. (2013). A field guide to the tracks and signs of southern, Central and East African wildlife. Cape Town, South Africa: Struik Nature.

Tinker, M.T. (2004). Sources of variation in the foraging behaviour and demography of the sea otter, Enhydra lutris. (Unpublished Ph.D. thesis). Santa Cruz, U.S.A.: University of California.

Tinker, M.T., Costa, D.P., Estes, J.A. \& Wieringa, N. (2007). Individual dietary specialization and dive behaviour in the California sea otter: Using archival time-depth data to detect alternative foraging strategies. Deep-Sea Research II, 54, 330-342.

van der Zee, D. (1981). Prey of the Cape clawless otter (Aonyx capensis) in the Tsitsikamma Coastal National
Park, South Africa. Journal of Zoology, London, 194, 467-483.

van Niekerk, C.H., Somers, M.J. \& Nel, J.A.J. (1998) Freshwater availability and distribution of Cape clawless otter spraints and resting places along the south-west coast of South Africa. South African Journal of Wildlife Research, 28, 68-72.

Verwoerd, D.J. (1987). Observations on the food and status of the Cape clawless otter, Aonyx capensis, at Betty's Bay, South Africa. South African Journal of Wildlife Research, 22, 33-39.

Watt, J., Siniff, D.B. \& Estes, J.A. (2000). Inter-decadal patterns of population and dietary change in sea otters at Amchitka Island, Alaska. Oecologia, 124, 289-298.

Whitfield, A.K. (1995). Available scientific information on individual South African estuarine systems. Report to the Water Research Commission by the Consortium for Estuarine Research and Management, WRC Report No. 577/1/95

Responsible Editor: E. Do Linh San 